\title{
Antioxidant activity and DNA protective properties of rice grass juices
}

\author{
Patipanee Khanthapok $^{\mathrm{a}}$, Amorntip Muangprom ${ }^{\mathrm{b}}$, Suchada Sukrong ${ }^{\mathrm{a}, *}$ \\ ${ }^{a}$ Department of Pharmacognosy and Pharmaceutical Botany, Faculty of Pharmaceutical Sciences, \\ Chulalongkorn University, Bangkok 10330 Thailand \\ b Rice Gene Discovery Unit, National Center for Genetic Engineering and Biotechnology (BIOTEC), \\ National Science and Technology Development Agency (NSTDA), Pathum Thani 12120 Thailand
}

*Corresponding author, e-mail: suchada.su@chula.ac.th

Received 30 Jun 2014

Accepted 11 May 2015

\begin{abstract}
Juice squeezed from cereal grasses harvested at the jointing stage, i.e., wheatgrass (Triticum aestivum), exhibits high antioxidant activity. Rice (Oryza sativa) may also exhibit antioxidant activity. We therefore examined the antioxidant activity of juices squeezed from grasses harvested at the jointing stage for seven coloured and seven white Thai rice cultivars. The antioxidant activity was determined using 2,2-diphenyl-1-picrylhydrazyl, ferric reducing antioxidant power, $\beta$-carotene bleaching, and thiobarbituric acid reactive substances assays. The total phenolic content (TPC) and total monomeric anthocyanin content (TMAC) were also determined. Coloured (purple) rice grass juices exhibited greater antioxidant potential than the grass juices from white rice and wheat. The coloured rice cultivar Kum Doisaket exhibited the highest antioxidant activity in all assays. Correlation analysis indicated that the TPC and TMAC could be responsible for the antioxidant activity. The DNA protective properties of the coloured rice cultivars Kum Doisaket and Kum Noi and wheat were also examined. Only the Kum Doisaket cultivar exhibited a dose-dependent DNA protective effect. The notable antioxidant efficacy for the Kum Doisaket cultivar may be influenced by the high level of anthocyanins present in its grass juice. This finding suggests the possibility of developing functional foods from coloured rice grass.
\end{abstract}

KEYWORDS: coloured rice, antioxidant potential, anthocyanin, the jointing stage, DNA protection

\section{INTRODUCTION}

Cereal grasses at the jointing stage are rich sources of antioxidants and phytonutrients ${ }^{1,2}$. Wheat (Triticum aestivum), an important cereal belonging to the Poaceae family, is a well-known example. Wheat grains have long been used as food ingredients. Juice squeezed from wheatgrass grown over a period of 6-10 days or to the jointing stage has been consumed as a health-promoting food and has been popular in the functional food market since the $1980^{1,3,4}$. Over the past two decades, numerous studies have investigated the active constituents and biological activities of extracts from wheatgrass harvested at the jointing stage. Wheatgrass juice exhibits a high antioxidant ${ }^{1}$ and immunomodulatory ${ }^{5}$ activity in mice. Furthermore, the antioxidant activity of wheat sprout extracts from 3- to 5-day-old young plants protect DNA from oxidative damage 4 . Interestingly, wheat sprout extracts have higher antioxidant activity than extracts from seeds after sprout detachment or non-sprouted seeds. Nonsprouted wheat seed extracts exhibit nearly undetectable antioxidant activity ${ }^{6}$. The antioxidant activity of wheatgrass juice suggests that grass juice from rice, other important cereal crop, may also exhibit antioxidant activity.

Rice (Oryza sativa), like wheat, is also a member of the Poaceae family. Both wheat and rice grains are staple foods for most populations in the world ${ }^{7}$. Rice is an important Thai economic crop and its grains are consumed as a major food, with various rice cultivars distributed throughout the country. Rice can be grouped into coloured and white rice according to the pericarp colour. Coloured rice grains possess coloured pericarps ranging from red to dark purple, whereas the pericarp of white rice is pale $^{8}$. The nutritional content, active compounds, antioxidant, biological activities of rice grains by examining their grains ${ }^{9}$, germinated grains ${ }^{10}$, and bran $^{11}$ of coloured and white rice have been investigated. Extracts from coloured rice exhibit 
greater antioxidant activity than those of white rice. Phenolic compounds and anthocyanins such as cyanidin-3-glucoside, peonidin-3-glucoside, and cyanidin diglucoside play an important role in the high antioxidant efficacy of coloured rice ${ }^{12}$. Furthermore, the chemical composition and antioxidant activity of rice extracts differ among different cultivars ${ }^{13}$. Based on the antioxidant potential of wheatgrass juice, the juice from Thai rice grasses harvested at the jointing stage is likely to possess compounds with antioxidant activity. As knowledge of the antioxidant activity of rice grass juice is limited $^{14}$, active compounds and biological activities of Thai rice grass juice should be investigated. Hence, the aim of this study was to determine the total phenolic content, total monomeric anthocyanin content, and antioxidant activity of grass juice from various cultivars of coloured and white rice and wheat using 2,2-diphenyl-1-picrylhydrazyl (DPPH), ferric reducing antioxidant power (FRAP), $\beta$-carotene bleaching (BCB), and thiobarbituric acid reactive substances (TBARS) assays. Furthermore, rice grass juices exhibiting strong antioxidant activity and a high level of total phenolic compounds or anthocyanins were also subjected to DNA nicking assays to evaluate DNA protective properties.

\section{MATERIALS AND METHODS}

\section{Chemicals and spectrophotometry}

The chemicals and reagents used in all experiments were of analytical and HPLC grade. The FolinCiocalteu reagent, 6-hydroxy-2,5,7,8-tetramethylchroman-2-carboxylic acid (Trolox), 2,2-diphenyl-1-picrylhydrazyl (DPPH), 2,4,6-tris(2-pyridyl)$s$-triazine (TPTZ), 2,6-di-tert-butyl-4-methylphenol (BHT) 2-thiobarbituric acid (TBA), $\beta$-carotene type II, $\mathrm{FeSO}_{4} \cdot 7 \mathrm{H}_{2} \mathrm{O}$, gallic acid, linoleic acid, trichloroacetic acid (TCA), 30\% (w/v) hydrogen peroxide, and TWEEN 40 were purchased from Sigma-Aldrich. Absolute ethanol was purchased from Merck Millipore (Merck). pBR322 DNA, the VC Lambda/HindIII marker, and agarose were purchased from Vivantis (Vivantis, Malaysia). Absorbance measurements to determine the total phenolic content, free radical scavenging activity, and ferric reducing antioxidant power were performed using a SpectraMax M5 Multi-Mode Microplate Reader and SoftMax Pro 5.2 software (Molecular Devices). An Evolution 600 UV-Vis Spectrophotometer (Thermo Fisher Scientific) was used to determine the anti-lipid peroxidation activity and total monomeric anthocyanin content.
Table 1 Rice and wheat cultivars used in this study.

\begin{tabular}{|c|c|c|}
\hline Sci. name & Cultivar & Code \\
\hline O. sativa ${ }^{\mathrm{a}}$ & $\begin{array}{l}\text { Kum Doisaket } \\
\text { Kum Ka } \\
\text { Kum Noi } \\
\text { Kum Pe } \\
\text { Kum Ton Khieaw } \\
\text { Niaw Dum Chor Mai Phi } \\
\text { Riceberry }\end{array}$ & $\begin{array}{l}\mathrm{C}-\mathrm{KDS}^{*} \\
\mathrm{C}-\mathrm{KK}^{\dagger} \\
\mathrm{C}-\mathrm{KN}^{\dagger} \\
\mathrm{C}-\mathrm{KP}^{\dagger} \\
\mathrm{C}-\mathrm{KTK}^{\dagger} \\
\mathrm{C}-\mathrm{NDP}^{\dagger} \\
\mathrm{C}-\mathrm{RB}^{\dagger}\end{array}$ \\
\hline O. sativa ${ }^{\mathrm{b}}$ & $\begin{array}{l}\text { Khai Mod Rin } 3 \\
\text { Khao Dawk Mali } 105 \\
\text { Khao Gaw Diaw } 35 \\
\text { Leb Nok Pattani } \\
\text { Pathum Thani } 1 \\
\text { Plai Ngahm Prachin Buri } \\
\text { RD6 }\end{array}$ & $\begin{array}{l}\text { W-KMR3 } \\
\text { W-KDML105 } \\
\text { W-KGD35 } \\
\text { W-LNP } \\
\text { W-PTT1 } \\
\text { W-PNPB }^{\dagger} \\
\text { W-RD6 }\end{array}$ \\
\hline T. aestivum ${ }^{\mathrm{c}}$ & Fang 60 & $\mathrm{WG}^{\dagger}$ \\
\hline \multicolumn{3}{|c|}{$\begin{array}{l}\text { a coloured; }{ }^{b} \text { white; }{ }^{c} \text { wheat. } \\
\text { " Purple Rice Research Unit, Chiang Mai University, } \\
\text { Chiang Mai. } \\
{ }^{\dagger} \text { Bureau of Seed Multiplication, Rice Department of } \\
\text { Thailand, Bangkok. }\end{array}$} \\
\hline
\end{tabular}

\section{Plant materials and juice preparation}

Seeds from coloured and white rice and wheat were obtained from the Bureau of Seed Multiplication of the Rice Department of Thailand in Bangkok and the Purple Rice Research Unit, Chiang Mai University, Chiang Mai, Thailand (Table 1). Rice and wheat seeds were washed and soaked overnight in tap water. After washing with distilled water, seeds were planted in vermiculite medium in plastic trays and were watered with tap water until the seeds germinated. Rice grass and wheatgrass were grown under fluorescent light (16/8 photoperiod) at $25 \pm 2{ }^{\circ} \mathrm{C}$ and were watered with $2.5 \mathrm{~g} / 1$ NPK (3020-10) fertilizer. At the jointing stage immediately prior to the emergence of the second leaf, fresh grasses were rapidly cut above ground, weighed, washed three times with tap water followed by distilled water, dry blotted, and immediately stored at $-20^{\circ} \mathrm{C}$. Ten grams of fresh grass were cut into small pieces and grounded twice with a pestle in a clean mortar containing $5 \mathrm{ml}$ of distilled water. Juices were squeezed through three layers of white cloth and centrifuged at $10000 \mathrm{~g}$ for $20 \mathrm{~min}$ at $4{ }^{\circ} \mathrm{C}$. Supernatants were filtered through $0.45-\mu \mathrm{m}$ syringe filters, lyophilized to a dry powder, and stored at $-20^{\circ} \mathrm{C}$. Lyophilized powders were reconstituted in distilled water at $20 \mathrm{mg}$ of dry extract per $\mathrm{ml}(\mathrm{mg}$ $\mathrm{DE} / \mathrm{ml}$ ), which was diluted to the final concentra- 
tion required in each assay. Colouration in seed husks, the pericarp, and grasses from coloured and white rice was also determined.

\section{Determination of the DPPH radical scavenging activity}

The radical scavenging activity of rice grass and wheatgrass juices was determined using a DPPH assay according to Brand-Williams et $\mathrm{al}^{15}$ with some modifications. Fifty micromolar ethanolic DPPH radical solution was reacted with $10-600 \mu \mathrm{g} \mathrm{DE} / \mathrm{ml}$ samples or $0.4-20 \mu \mathrm{M}$ Trolox. Distilled water and absolute ethanol were used as blanks for the samples and for trolox, respectively. After $30 \mathrm{~min}$, the absorbance of DPPH radicals in solution was measured at $517 \mathrm{~nm}$ against a blank using a microplate reader. The percentage of the radical scavenging activity of the samples and trolox was calculated and plotted against different sample or trolox concentrations to obtain the $\mathrm{EC}_{50}(\mathrm{mg} \mathrm{DE} / \mathrm{ml})$. The $\mathrm{EC}_{50}$ represents the amount of sample required to scavenge $50 \%$ of the initial DPPH concentration.

\section{FRAP determination}

The FRAP value of the samples was evaluated using a modified FRAP assay according to Benzie and Strain ${ }^{16}$. A freshly prepared FRAP working solution

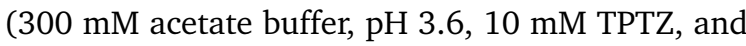
$20 \mathrm{mM} \mathrm{FeCl}_{3}$ ) was allowed to react with $400 \mu \mathrm{g}$ $\mathrm{DE} / \mathrm{ml}$ samples or $400 \mu \mathrm{g} / \mathrm{ml}$ trolox or $5-100 \mu \mathrm{M}$ $\mathrm{FeSO}_{4}$ for $30 \mathrm{~min}$ in the dark. The absorbance of the reaction mixtures was measured at $593 \mathrm{~nm}$, and a standard curve for $\mathrm{FeSO}_{4}$ was plotted. The FRAP value was calculated from the standard curve and is expressed in molar $\mathrm{Fe}^{2+}$ per gram dry extract (M $\left.\mathrm{Fe}^{2+} / \mathrm{g} \mathrm{DE}\right)$.

\section{$\beta$-Carotene bleaching assay}

The anti-lipid peroxidation activity of rice grass and wheatgrass juices was determined using a modified $\mathrm{BCB}$ assay according to Takada et $\mathrm{al}^{17}$. $\beta$-carotene/linoleic acid emulsions $(2 \mathrm{mg}$ of $\beta$-carotene, $80 \mathrm{mg}$ of linoleic acid, and $800 \mathrm{mg}$ of TWEEN 40) were incubated with $800 \mu \mathrm{g} \mathrm{DE} / \mathrm{ml}$ samples or $800 \mu \mathrm{g} / \mathrm{ml} \mathrm{BHT}$ at $50^{\circ} \mathrm{C}$ for $2 \mathrm{~h}$. Aerated distilled water was used as a control. A linoleic acid emulsion without $\beta$-carotene was used as a blank. The absorbance of the mixtures was measured at $470 \mathrm{~nm}$ in 20 min intervals for 120 min against the blank. The percent inhibition of lipid peroxidation was calculated as $(100 \%)\left[1-\left(\Delta A_{\text {sample }} / \Delta A_{\text {control }}\right)\right]$, where $\Delta A_{\text {sample }}$ and $\Delta A_{\text {control }}$ are the difference between the absorbance at $t=0$ and $t=120 \mathrm{~min}$ for the sample and control, respectively.

\section{TBARS assay}

The inhibitory effects on lipid peroxidation by rice grass and wheatgrass juices were evaluated by measuring TBARS according to a method described by Tee et $\mathrm{al}^{18}$ and Nagababu et al ${ }^{19}$ with minor modifications. The linoleic acid model system $(10 \mathrm{mM}$ linoleic acid, $10 \mathrm{mM}$ TWEEN 40, and $0.1 \mathrm{M} \mathrm{Na}_{3} \mathrm{PO}_{4}$ buffer, $\mathrm{pH}$ 7.0) was co-incubated with $800 \mu \mathrm{g} \mathrm{DE} / \mathrm{ml}$ samples or $800 \mu \mathrm{g} / \mathrm{ml} \mathrm{BHT,} 0.4 \mathrm{mM}$ ascorbic acid, and $0.4 \mathrm{mM} \mathrm{FeSO}_{4}$ at $45^{\circ} \mathrm{C}$ for $1 \mathrm{~h}$. Distilled water was used as a control. After incubation, $10 \mathrm{mM}$ BHT, $45 \%(\mathrm{w} / \mathrm{v}) \mathrm{TCA}$, and $2 \%(\mathrm{w} / \mathrm{v})$ TBA were sequentially added to the reaction mixture, heated to $95^{\circ} \mathrm{C}$ for $10 \mathrm{~min}$, and then cooled down on ice. Reaction mixtures were centrifuged, and the supernatants were collected. The absorbance was measured at $532 \mathrm{~nm}$ against a blank containing all the reagents except ascorbic acid and $\mathrm{FeSO}_{4}$. The percent inhibition of lipid peroxidation was calculated as $(100 \%)\left[1-\left(A_{\text {sample }} / A_{\text {control }}\right)\right]$, where $A_{\text {sample }}$ and $A_{\text {control }}$ are the absorbances of TBARS produced in a reaction mixture at $532 \mathrm{~nm}$ for the sample and control, respectively.

\section{Total phenolic content determination}

The total phenolic compound (TPC) in rice grass and wheatgrass juices was determined using the FolinCiocalteu method according to Singleton et $\mathrm{al}^{20}$ with some modifications. The Folin-Ciocalteu reagent at a concentration of $0.2 \mathrm{~N}$ was reacted with $400 \mu \mathrm{g} / \mathrm{ml}$ samples or $1-50 \mu \mathrm{g}$ of gallic acid and incubated in the dark. After $5 \mathrm{~min}, 8 \%(\mathrm{w} / \mathrm{v})$ $\mathrm{Na}_{2} \mathrm{CO}_{3}$ was added to the reaction mixtures, which were maintained in the dark at room temperature for $30 \mathrm{~min}$. The absorbance of the blue solution was measured at $765 \mathrm{~nm}$ and plotted against the gallic acid concentrations. The TPC was calculated from a standard curve of gallic acid and is expressed as milligrams of gallic acid equivalents per gram of dry extract (mg GAE/g DE).

\section{Total monomeric anthocyanin content determination}

The total monomeric anthocyanin content (TMAC) in rice grass and wheatgrass juices was determined using the $\mathrm{pH}$ differential method as described by Lee et $\mathrm{al}^{21}$. Samples were diluted 1:8 with $25 \mathrm{mM} \mathrm{KCl}$ buffer, $\mathrm{pH} 1.0$, and $400 \mathrm{mM}$ sodium acetate buffer, $\mathrm{pH}$ 4.5. The absorbance of samples in different $\mathrm{pH}$ value systems was measured at 520 and $700 \mathrm{~nm}$. 
The TMAC is expressed as milligrams of cyanidin3-glucoside equivalents per gram of dry extract ( $\mathrm{mg}$ C3GE/g DE) and was calculated as follows:

$$
\mathrm{TMAC}=\frac{A M f B}{\varepsilon L \rho},
$$

where $A=\left(A_{520}-A_{700}\right)_{\mathrm{pH} 1.0}-\left(A_{520}-A_{700}\right)_{\mathrm{pH} 4.5}$ with $A_{520}$ and $A_{700}$ the absorbance at $520 \mathrm{~nm}$ and $700 \mathrm{~nm} ; M$ is the molecular weight of C3GE, $449.2 \mathrm{~g} / \mathrm{mol} ; f$, a dilution factor; $B$, the conversion factor $1000 \mathrm{mg} / \mathrm{g} ; \varepsilon$, the molar extinction coefficient for C3GE, $269001 \mathrm{~mol}^{-1} \mathrm{~cm}^{-1}$; $L$, the path length, $1 \mathrm{~cm}$; and $\rho$, the concentration of the sample $(\mathrm{g} / \mathrm{l})$.

\section{Assessment of the protection against oxidative DNA damage}

The DNA protective properties of rice grass and wheatgrass juices were assessed by subjecting supercoiled pBR322 DNA to the Fenton reaction according to the method described by Falcioni et $\mathrm{al}^{4}$ with some modifications. Two hundred nanograms of pBR322 DNA were incubated with samples at 1, 10, and $100 \mu \mathrm{g} \mathrm{DE} / \mathrm{ml}$ at room temperature for $10 \mathrm{~min}$. Subsequently, $100 \mu \mathrm{M} \mathrm{FeSO}_{4}$ and $80 \mathrm{mM} \mathrm{H}_{2} \mathrm{O}_{2}$ were added to the mixture. The final volume of the mixture was brought to $20 \mu \mathrm{l}$ with $5 \mathrm{mM} \mathrm{Na}_{3} \mathrm{PO}_{4}$ buffer, $\mathrm{pH} 7.4$, and the mixture was incubated at $37^{\circ} \mathrm{C}$ for $1 \mathrm{~h}$. The reaction was terminated by adding $6 \times$ electrophoresis loading buffer which comprises $0.25 \%(\mathrm{w} / \mathrm{v})$ bromophenol blue, $0.25 \%(\mathrm{w} / \mathrm{v}) \mathrm{xy}-$ lene cyanol FF, and 30\% (v/v) glycerol. Treated pBR322 DNA was separated in a $1 \%(\mathrm{w} / \mathrm{v})$ agarose gel along with the VC Lambda/HindIII marker and stained with ethidium bromide. pBR322 DNA was visualized and photographed under UV light using a Gel Doc XR+ system (Bio-Rad). The relative intensity of the supercoiled pBR322 DNA following exposure to the Fenton reaction was quantified and calculated as a percentage using Image Lab software (Bio-Rad). Distilled water and $0.1 \mu \mathrm{M}$ Trolox were used as a control and a positive control, respectively.

\section{Statistical analysis}

All assays were performed in triplicate $(n=3)$ and the results were reported as the means $\pm S D$. The data were analysed using Tukey's HSD test in ANOVA using SPSS software, version 16.0 (SPSS Inc.). Significant differences were considered at $p<0.05$. Correlation analysis between assays was performed using Pearson's correlation coefficient $(R)$.

\section{RESULTS}

\section{Colouration of rice}

Seven cultivars from both coloured and white rice and one wheat cultivar were examined in this study (Table 1). Colour differences were observed in the seed husk, pericarp, and rice grass (Fig. 1). The colour of the white rice seed husks was light to dark yellow, whereas that of the seed husks of the coloured rice ranged from light yellow to dark brown (Fig. 1a). Only the coloured rice cultivars possessed coloured pericarps ranging from red/reddish-brown to dark brown or reddish-purple to dark purple (Fig. 1a). The anthocyanin pigmentation was observed in grasses of six coloured rice cultivars: C-KDS, C-KK, C-KN, C-KP, C-KTK, and CRB. Pigments accumulated in the coleoptiles and leaves of coloured grass, and their colour varied from reddish-purple to dark purple. Interestingly, grasses of the coloured rice cultivar C-NDP were green, which is similar to that of the white rice cultivars and wheat (Fig. 1b). The colour of the fresh juice and dry extract of the rice grass and wheatgrass ranged from green to dark purple depending on the anthocyanin pigmentation of the grass (Fig. 1c and Fig. 1d).

\section{DPPH and FRAP assays}

The radical scavenging activity and ferric reducing ability of grass juices were evaluated using DPPH and FRAP assays, respectively. The DPPH radical scavenging activity of the samples is expressed as the $\mathrm{EC}_{50}$ value (Table 2). Rice grass and wheatgrass juices at concentrations ranging from 10-600 $\mu \mathrm{g}$ $\mathrm{DE} / \mathrm{ml}$ exhibited DPPH radical scavenging activity in a dose-dependent manner (Fig. 2). Generally, the coloured juices of most of the coloured rice cultivars exhibit a strong DPPH radical scavenging activity. The C-KDS cultivar exhibited the greatest radical scavenging activity with an $\mathrm{EC}_{50}$ of $0.11 \mathrm{mg} \mathrm{DE} / \mathrm{ml}$. The coloured rice cultivars C-KDS, C-KK, C-KN, CKP, C-KTK, and C-RB exhibited a significantly greater DPPH radical scavenging activity than white rice cultivars and wheat. The green juice of the coloured rice cultivar C-NDP exhibited however a lower radical scavenging activity than wheat. Coloured and white rice grass juices could reduce $\mathrm{Fe}^{3+}$ to $\mathrm{Fe}^{2+}$. FRAP values indicate that coloured rice cultivars exhibited a higher $\mathrm{Fe}^{3+}$ reducing capacity than white rice cultivars (Table 2). The coloured rice cultivar C-KDS exhibited the highest FRAP value of $1.79 \pm 0.03 \mathrm{M} \mathrm{Fe}^{2+} / \mathrm{g}$ DE. In contrast, the white rice cultivar W-PNPB exhibited the lowest FRAP value of 
(a)

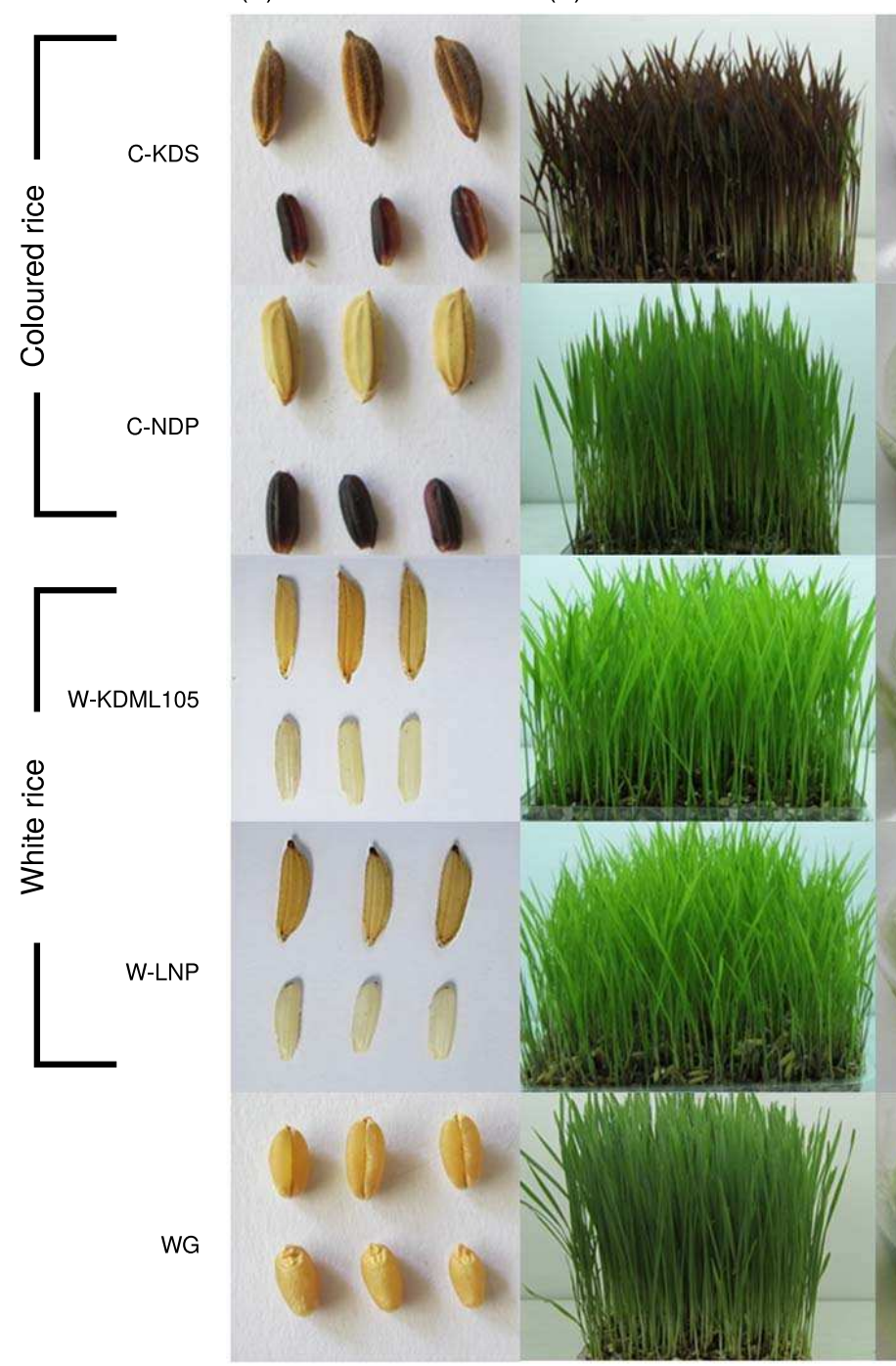

(c)

(d)

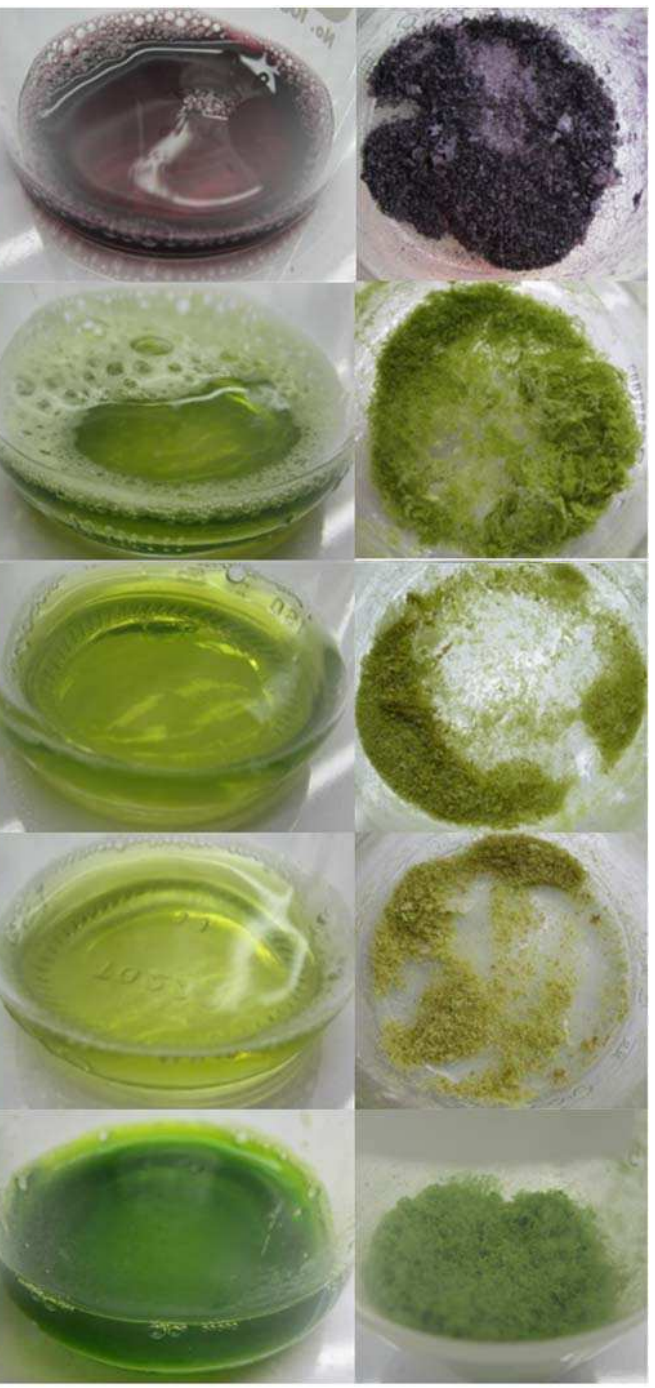

Fig. 1 Colour differences of (a) the seed husk and pericarp, (b) grasses, (c) fresh grass juice, and (d) the dry extract of the coloured rice cultivars C-KDS and C-NDP, white rice cultivars W-KDML105 and W-LNP, and wheat (WG).

$$
0.44 \pm 0.03 \mathrm{M} \mathrm{Fe}^{2+} / \mathrm{g} \mathrm{DE}
$$

\section{Inhibition of lipid peroxidation}

The anti-lipid peroxidation activity of rice grass and wheatgrass juices was evaluated using BCB and TBARS assays. Grass juices from coloured rice, white rice and wheat at a concentration of $800 \mu \mathrm{g}$ $\mathrm{DE} / \mathrm{ml}$ were subjected to the linoleic acid emulsion system to determine the percent inhibition of $\beta$-carotene bleaching and TBARS formation (Table 1). Coloured juices from coloured rice cultivars exhibited a strong inhibitory effect on lipid peroxidation. The C-KDS cultivar exhibited the greatest anti-lipid peroxidation activity among the examined cultivars with $93.8 \pm 1.2 \% \beta$-carotene bleaching and $95.0 \pm 0.3 \%$ TBARS formation compared with that of the control. However, the green juice from the coloured rice cultivar C-NDP exhibited moderate anti-lipid peroxidation activity in BCB and TBARS assays. The anti-lipid peroxidation activity of white rice cultivars was low to moderate. The W-PTT1 cultivar exhibited the lowest inhibition of the lipid peroxidation, with $8.7 \pm 1.3$ and $12.5 \pm 0.4 \% \beta$-carotene bleaching and TBARS formation, respectively.

\section{TCP and total monomeric anthocyanin content}

Samples were subjected to a modified Folin-Ciocalteu method for TPC determination (Fig. 3). The 
Table 2 DPPH radical scavenging activity, ferric reducing capacity (FRAP values), and anti-lipid peroxidation activity in the $\beta$-carotene/linoleic acid system ( $\beta$-carotene bleaching assay, $\mathrm{BCB}$ ) and the ascorbate- $\mathrm{Fe}^{2+}$ system (thiobarbituric acid reactive substances, TBARS) of rice grass and wheatgrass juices.".

\begin{tabular}{|c|c|c|c|c|}
\hline \multirow[t]{2}{*}{ Samples } & \multirow{2}{*}{$\begin{array}{c}\text { DPPH assay } \\
\mathrm{EC}_{50}(\mathrm{mg} / \mathrm{ml})^{\dagger}\end{array}$} & \multirow{2}{*}{$\begin{array}{l}\text { FRAP values } \\
\left(\mathrm{M} \mathrm{Fe}^{2+} / \mathrm{g} \mathrm{DE}\right)\end{array}$} & \multicolumn{2}{|c|}{ Inhibition of lipid peroxidation (\%) } \\
\hline & & & $\mathrm{BCB}$ & TBARS \\
\hline C-KDS & $0.11 \pm 0.03^{\mathrm{a}}$ & $1.79 \pm 0.03^{\mathrm{a}}$ & $93.8 \pm 1.2^{\mathrm{a}}$ & $95.0 \pm 0.3^{\mathrm{a}}$ \\
\hline C-KK & $0.64 \pm 0.02^{c}$ & $1.13 \pm 0.03^{\mathrm{c}, \mathrm{d}}$ & $91.5 \pm 1.7^{\mathrm{a}, \mathrm{b}}$ & $92.7 \pm 0.5^{\mathrm{b}}$ \\
\hline $\mathrm{C}-\mathrm{KN}$ & $0.54 \pm 0.07^{\mathrm{b}, \mathrm{c}}$ & $0.61 \pm 0.02^{f}$ & $91.7 \pm 0.7^{\mathrm{a}, \mathrm{b}}$ & $93.2 \pm 0.9^{\mathrm{a}, \mathrm{b}}$ \\
\hline $\mathrm{C}-\mathrm{KP}$ & $0.61 \pm 0.05^{c}$ & $1.18 \pm 0.04^{\mathrm{c}, \mathrm{d}}$ & $91.0 \pm 0.4^{\mathrm{b}}$ & $92.6 \pm 0.7^{b}$ \\
\hline C-KTK & $0.67 \pm 0.03^{c}$ & $0.73 \pm 0.03^{\mathrm{e}}$ & $90.3 \pm 1.0^{\mathrm{b}}$ & $91.8 \pm 0.6^{\mathrm{b}}$ \\
\hline C-NDP & $1.02 \pm 0.02^{\mathrm{e}}$ & $0.61 \pm 0.02^{\mathrm{f}}$ & $64.5 \pm 1.1^{\mathrm{e}}$ & $67.3 \pm 1.2^{\mathrm{d}}$ \\
\hline $\mathrm{C}-\mathrm{RB}$ & $0.43 \pm 0.06^{\mathrm{b}}$ & $1.06 \pm 0.03^{\mathrm{d}}$ & $81.3 \pm 1.7^{\mathrm{c}}$ & $83.5 \pm 0.7^{c}$ \\
\hline W-KMR3 & $1.02 \pm 0.01^{\mathrm{e}}$ & $0.50 \pm 0.02^{g}$ & $65.1 \pm 1.0^{\mathrm{e}}$ & $68.4 \pm 0.9^{d}$ \\
\hline W-KDML105 & $11.36 \pm 0.07^{\mathrm{f}}$ & $0.47 \pm 0.07^{g, h}$ & $41.2 \pm 0.6^{\mathrm{h}}$ & $46.6 \pm 0.7^{\mathrm{f}, \mathrm{g}}$ \\
\hline W-KGD35 & $0.98 \pm 0.04^{\mathrm{e}}$ & $0.54 \pm 0.01^{g}$ & $56.4 \pm 0.7^{\mathrm{f}}$ & $57.9 \pm 1.2^{\mathrm{e}}$ \\
\hline W-LNP & $1.34 \pm 0.08^{f}$ & $1.31 \pm 0.04^{\mathrm{b}}$ & $56.5 \pm 1.0^{f}$ & $59.6 \pm 1.4^{\mathrm{e}}$ \\
\hline W-PNPB & $1.90 \pm 0.05^{g}$ & $0.44 \pm 0.03^{h}$ & $40.1 \pm 1.9^{\mathrm{h}}$ & $41.7 \pm 1.7^{g}$ \\
\hline W-PTT1 & $1.94 \pm 0.06^{g}$ & $0.48 \pm 0.03^{g, h}$ & $8.7 \pm 1.3^{\mathrm{i}}$ & $12.5 \pm 0.4^{\mathrm{h}}$ \\
\hline W-RD6 & $1.24 \pm 0.03^{\mathrm{f}}$ & $0.53 \pm 0.01^{g}$ & $40.3 \pm 0.4^{\mathrm{h}}$ & $45.0 \pm 0.9^{g}$ \\
\hline Wheatgrass & $0.81 \pm 0.02^{\mathrm{d}}$ & $1.08 \pm 0.02^{\mathrm{d}}$ & $47.8 \pm 0.8^{g}$ & $49.4 \pm 0.2^{f}$ \\
\hline \multirow[t]{2}{*}{ Standard } & Trolox & Trolox & BHT & BHT \\
\hline & $2.43 \pm 0.05 \mu \mathrm{g} / \mathrm{ml}$ & $770 \pm 12^{\uparrow}$ & $83.3 \pm 1.1$ & $86.7 \pm 0.1$ \\
\hline
\end{tabular}

"Values are expressed as the mean of triplicates $\pm \mathrm{SD} .{ }^{\dagger} \mathrm{EC}_{50}$ represents the effective concentration of the samples or trolox that can scavenge $50 \%$ of the initial DPPH concentration. ${ }^{*}$ The concentration of samples and standard used in the BCB and TBARS assays was $800 \mu \mathrm{g} / \mathrm{ml}$. ${ }^{\top}$ The value is expressed in $\mathrm{M} \mathrm{Fe}^{2+} / \mathrm{g}$ trolox.

Different letters within the same column indicate a significant difference at $p<0.05$ by Tukey's HSD test.

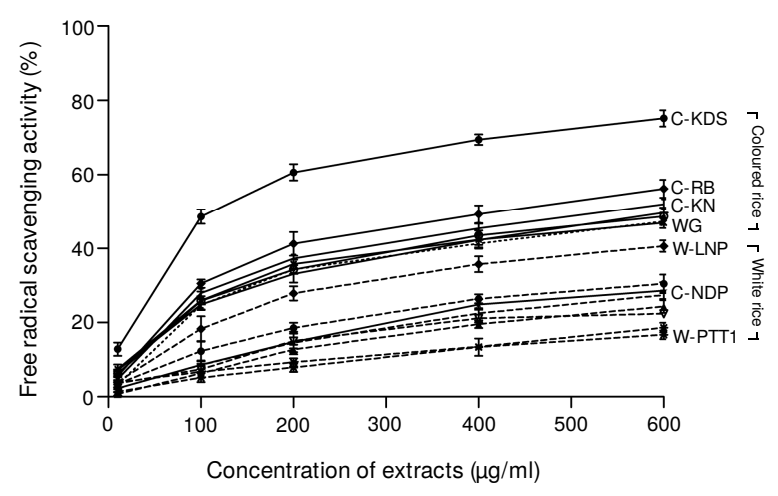

Fig. 2 DPPH radical scavenging activity (\%) of grass juices from seven coloured rice cultivars (solid line), seven white rice cultivars (dashed line), and wheat (dotted line) at concentrations ranging from $10-600 \mu \mathrm{g} / \mathrm{ml}$. Coloured rice cultivars C-KDS, C-RB, C-KN, and C-NDP; white rice cultivars W-LNP and W-PTT1; and wheat (WG).

TPC of the coloured rice cultivars ranged from 1.9$4.3 \mathrm{mg}$ GAE/g DE. The C-KDS cultivar exhibited the highest TPC. The TPC of white rice cultivars varied in the range 1.50-2.14 $\mathrm{mg} \mathrm{GAE} / \mathrm{g} \mathrm{DE}$, whereas the TPC of wheat was $2.91 \pm 0.1 \mathrm{mg}$ GAE/g DE. The
TPC of C-KDS grass juice was 1.47 and 2.86 times higher than that of wheat and white rice cultivar W-KMR3, respectively. The coloured grass juices, particularly C-KDS, exhibited more effective antioxidant activity than the green grass juices. To determine whether the antioxidant activity of coloured rice cultivars was influenced by the presence of anthocyanins, the $\mathrm{pH}$ differential method was performed. Monomeric anthocyanins were detected in only the coloured grass juices of the coloured rice cultivars C-KDS, C-KK, C-KN, C-KP, C-KTK, and C-RB (Fig. 4). The C-KDS cultivar exhibited the highest TMAC at $4.42 \mathrm{mg}$ C3GE/g DE. The TMAC in grass juice from the C-KDS cultivar was 2- and 15-fold greater than that from the $\mathrm{C}-\mathrm{KK}$ and $\mathrm{C}-\mathrm{KN}$ cultivars, respectively.

\section{Correlation analysis of the antioxidant activity, TPC, and TMAC}

To determine the relationship between the different antioxidant activity assays, TPC, and TMAC of rice grass juices, Pearson correlation analysis was performed. Significant correlations were found among the assays with $p<0.05$ (Table 3). The TPC and TMAC were associated with antioxidant 


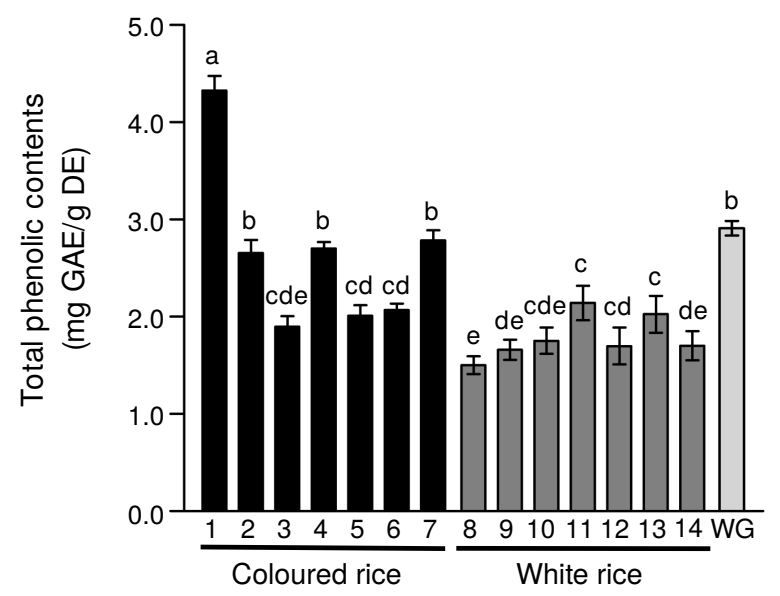

Fig. 3 Total phenolic content of grass juice from coloured rice (1: C-KDS; 2: C-KK; 3: C-KN; 4: C-KP; 5: C-KTK; 6: C-NDP; and 7: C-RB), white rice (8: W-KMR3; 9: WKDML105; 10: W-KGD35; 11: W-LNP; 12: W-PTT1; 13: W-PNPB; and 14: W-RD6) and wheat (WG). The values are expressed as milligrams of gallic acid equivalents per gram of dry extract (mg GAE/g DE). Different letters above the bars indicate a significant difference at $p<$ 0.05 .

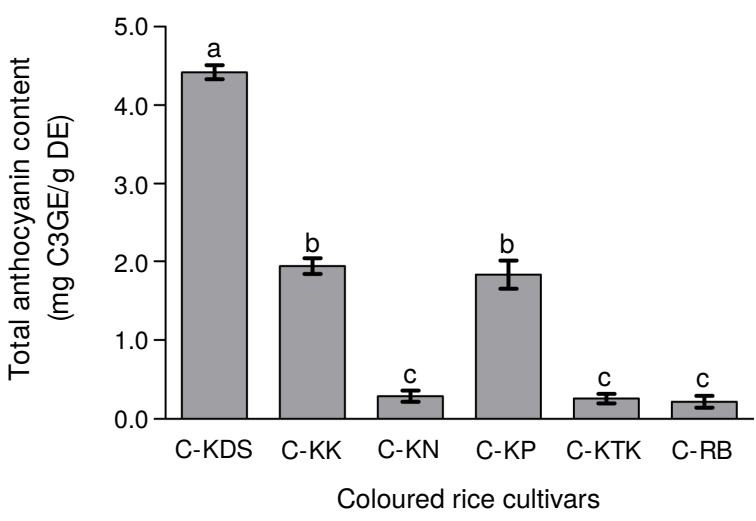

Fig. 4 Total monomeric anthocyanin content of coloured rice grass juices. The values are expressed as milligrams of cyanidin-3-glucoside equivalents per gram of dry extract (mg C3GE/g DE). Different letters above the bars indicate a significant difference at $p<0.05$.

activity. Furthermore, the TMAC exhibited greater correlation with the anti-lipid peroxidation activity than the TPC.

\section{DNA strand breakage inhibition}

The ability of grass juices from the rice cultivars $\mathrm{C}-\mathrm{KDS}$ and C-KN to prevent oxidative damage of supercoiled pBR322 DNA was determined and compared to that of wheat (Fig. 5). After subjecting
Table 3 Correlation coefficients $(R)$ between antioxidant activity assays, total phenolic content, and total monomeric anthocyanin content.

\begin{tabular}{llllll}
\hline & \multicolumn{5}{c}{ Correlation coefficients $(R)$} \\
\cline { 2 - 6 } & DPPH & FRAP & BCB & TBARS & TPC \\
\hline FRAP & $0.843^{*}$ & & & & \\
BCB & $0.786^{*}$ & $0.584^{*}$ & & & \\
TBARS & $0.773^{*}$ & $0.546^{*}$ & $0.993^{*}$ & & \\
TPC & $0.784^{*}$ & $0.880^{*}$ & $0.491^{*}$ & 0.458 & \\
TMAC & $0.694^{*}$ & $0.792^{*}$ & $0.533^{*}$ & $0.503^{*}$ & $0.845^{*}$ \\
\hline
\end{tabular}

DPPH: DPPH radical scavenging activity; FRAP: ferric reducing antioxidant power; $\mathrm{BCB}$ : $\beta$-carotene bleaching assay; TBARS: thiobarbituric acid reactive substances; TPC: total phenolic content; TMAC: total monomeric anthocyanin content.

Significant at $p<0.05$.

pBR322 DNA to the Fenton reaction, 3 pBR322 DNA bands were detected under UV light. The upper band represents a nicked circular (NC) form, which is followed by linear and supercoiled (SC) pBR322 DNA (Fig. 5a). Most of the pBR322 DNA in the control reaction (SC lane) was in a supercoiled form. In the presence of ferrous ion $\left(\mathrm{Fe}^{2+}\right.$ lane) or hydrogen peroxide alone $\left(\mathrm{H}_{2} \mathrm{O}_{2}\right.$ lane), pBR322 DNA was partially converted to the NC form. However, the SC DNA was completely converted to the NC and linear forms when incubated with both ferrous ion and hydrogen peroxide $\left(\mathrm{Fe}^{2+} / \mathrm{H}_{2} \mathrm{O}_{2}\right.$ lane). The positive control ( $0.1 \mu \mathrm{M}$ Trolox) demonstrated a potent DNA protective effect. The relative intensity of the SC DNA was $85.1 \pm 3 \%$ compared with that of the control (Fig. 5b). The coloured rice cultivar C-KDS demonstrated a dose-dependent DNA protective effect. The relative intensity of the SC DNA was significantly increased from $31.5 \pm 1.3-37.5 \pm 2 \%$ upon co-incubation of pBR322 DNA and C-KDS grass juice at 1 and $100 \mu \mathrm{g} / \mathrm{ml}$, respectively (Fig. 5a and 5b). Juice from the C-KN cultivar at concentrations of 1 , 10 , and $100 \mu \mathrm{g} / \mathrm{ml}$ exhibited DNA protective effects, but the effect was lower for $100 \mu \mathrm{g} / \mathrm{ml}$. A DNA protective effect was also observed upon co-incubation of pBR322 DNA with $1 \mu \mathrm{g} / \mathrm{ml}$ wheatgrass juice, which exhibited a relative intensity for SC DNA of $21.8 \pm 2 \%$ (Fig. $5 \mathrm{~b}$ ). However, wheatgrass juice at higher concentrations promoted oxidative damage of pBR322 DNA. The greatest pro-oxidant activity was observed for $100 \mu \mathrm{g} / \mathrm{ml}$ wheatgrass juice, which resulted in completely fragmented DNA (Fig. 5a). 

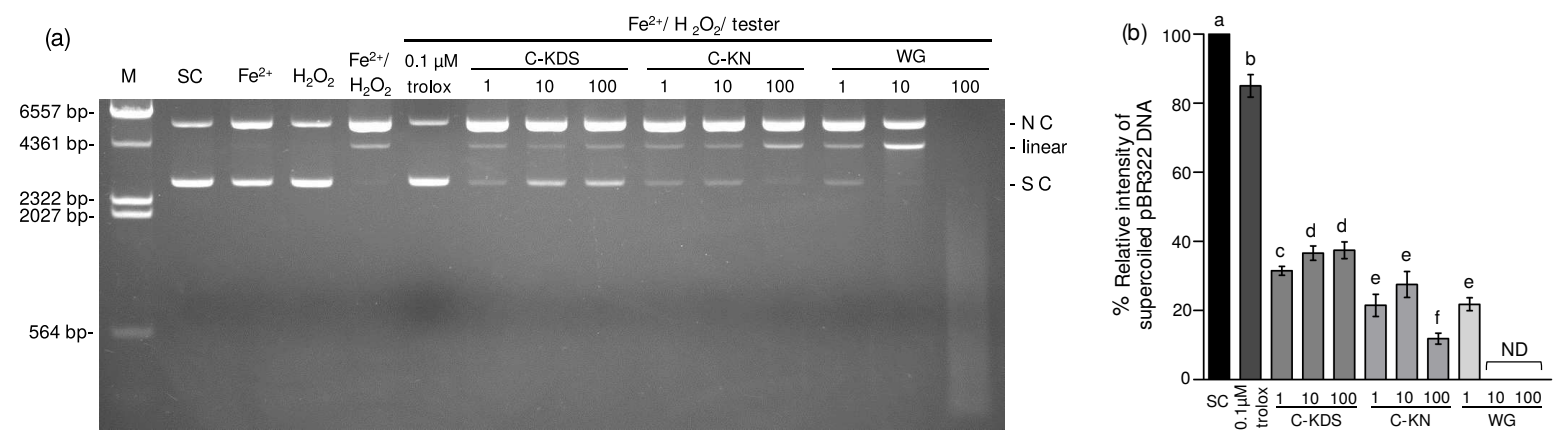

Fig. 5 DNA protective effects of grass juice from the coloured rice cultivars Kum Doisaket (C-KDS) and Kum Noi (C-KN), and wheat (WG). (a) Agarose gel electrophoresis of pBR322 DNA following exposure to the Fenton reaction. M: the VC Lambda/HindIII marker; SC: supercoiled pBR322 DNA; NC: nicked pBR322 DNA; Fe ${ }^{2+}$ : DNA $+\mathrm{Fe}^{2+} ; \mathrm{H}_{2} \mathrm{O}_{2}$ : DNA $+\mathrm{H}_{2} \mathrm{O}_{2} ; \mathrm{Fe}^{2+} / \mathrm{H}_{2} \mathrm{O}_{2}$ : DNA $+\mathrm{Fe}^{2+}+\mathrm{H}_{2} \mathrm{O}_{2}$; and $\mathrm{Fe}^{2+} / \mathrm{H}_{2} \mathrm{O}_{2} /$ tester: DNA $+\mathrm{Fe}^{2+}+\mathrm{H}_{2} \mathrm{O}_{2}+0.1 \mu \mathrm{M}$ trolox or 1, 10, and $100 \mu \mathrm{g} / \mathrm{ml}$ of C-KDS, C-KN, or WG grass juices. (b) The relative intensity of supercoiled pBR322 DNA subjected to the Fenton reaction in the presence of $0.1 \mu \mathrm{M}$ trolox or 1,10 , and $100 \mu \mathrm{g} / \mathrm{ml}$ of the C-KDS, C-KN, or WG grass juices. The relative intensity of the control (SC) is set at $100 \%$. Different letters above the bars indicate a significant difference at $p<0.05$.

\section{DISCUSSION}

Wheat is an important cereal crop. Wheat products such as wheat germ, bran, seeds, and flour are important ingredients in the food industry. In the functional food market, wheatgrass harvested at the jointing stage (i.e., 6-10 days-old young plants) is a popular health-promoting food ${ }^{2-4}$. The active compounds and biological activities of wheatgrass juice and extracts have been investigated in numerous studies. Aqueous and ethanolic extracts from 6-15 day-old wheatgrass were found to exhibit high antioxidant activity. The highest antioxidant activity was found for aqueous extracts from 7-dayold wheatgrass ${ }^{1}$. Wheatgrass juice stimulates the immune system of normal and predsinolone-treated Swiss albino mice ${ }^{5}$. Furthermore, wheatgrass juice is an effective treatment in clinical trials of active distal ulcerative colitis ${ }^{22}$ and prevents myelotoxicity from chemotherapy in breast cancer patient ${ }^{23}$. Additionally, extracts from wheat sprouts grown over a period of 3-5 days inhibit the mutagenic activity of benzo[a]pyrene in rats. Apigenin and its derivatives that are present in wheat sprout extracts were identified as the active constituents ${ }^{24}$. A wheat sprout extract containing antioxidant glycosides also exhibited DNA protective effects ${ }^{4}$. Moreover, the antioxidant potency of wheat sprout extracts was higher than that of extracts from seeds after sprout detachment and non-sprouted seeds. Reducing glycosides and polyphenolic compounds are responsible for the high reducing and radical scavenging activities of wheat sprout extracts, whereas non-sprouted wheat seed extracts exhibit the lowest antioxidant activity, which is nearly undetected ${ }^{6}$. These informative studies on wheatgrass juice suggested that other cereal grasses, such as rice, may also exhibit antioxidant activity.

Rice is a staple food and an economic cereal crop. Various rice cultivars have been distributed and are cultivated throughout Thailand. The pericarp colour of rice grains can be used to classify rice cultivars into coloured and white rice ${ }^{8}$. The antioxidant activity of bran, grains, and germinated grains from both rice types has been widely reported. Most studies have indicated that products from coloured rice have a higher antioxidant activity than that of white rice ${ }^{9-11}$. Although most studies have investigated the antioxidant activity of rice bran $^{11}$, grains ${ }^{9}$, and germinated grains ${ }^{10}$, some have also investigated the activities of juice and extracts from rice seedlings. Seedling juices from a coloured rice cultivar and four white rice cultivars exhibited a higher total antioxidant capacity than wheatgrass juice ${ }^{14}$. These reports on wheatgrass and rice seedling extracts suggest that juices from coloured and white rice grasses harvested at the jointing stage may potentially exhibit antioxidant activity.

In this study, grass juices were prepared and processed without high-temperature treatment to preserve thermally sensitive antioxidants, and solvents were not utilized to eliminate solvent effects $^{6,25}$. Natural antioxidants in crude plant extracts possess multifunctional activities; thus a single antioxidant activity assay might be insufficient 
to predict and measure the antioxidant efficacy of natural antioxidants ${ }^{25-28}$. The utilization of assays that measure electron/radical scavenging activity in combination with anti-lipid peroxidation assays is recommended for the determination of natural antioxidant potential ${ }^{29}$. We conducted therefore four different antioxidant assays, i.e., DPPH, FRAP, $\mathrm{BCB}$, and TBARS assays, to determine the antioxidant efficacy of wheatgrass and coloured and white rice grass juices. Rice grass and wheatgrass juices exhibited antioxidant activity in different assays (Table 2). Positive results in all the antioxidant activity assays used in this study indicate that the various antioxidants present in rice grass and wheatgrass juices include a DPPH radical scavenger, a metal ion chelator, and a lipid peroxidation inhibitor ${ }^{29}$. Interestingly, coloured grasses from most of the coloured rice cultivars exhibit a high level of anthocyanins in the coleoptiles and leaves (Fig. 1). Coloured grass juices demonstrated more effective antioxidant activity than green juices. Our results are consistent with the observed antioxidant efficacy of rice bran, in which coloured rice bran exhibited stronger antioxidant activity than white rice bran ${ }^{11}$. Notably, the most coloured rice cultivar Kum Doisaket significantly exhibited the highest antioxidant efficacy in all assays.

Phenolic compounds are water-soluble antioxidants that are commonly found in fruits, vegetables, and plant extracts. Hydroxyl groups and their resonance stabilization effects on the phenol rings of phenolic compounds are responsible for plant antioxidant activity ${ }^{30-33}$. A positive correlation between antioxidant activity and the phenolic content of crude extracts has been demonstrated among different plant parts and species such as rice bran ${ }^{11}$, wild Indian black plums ${ }^{34}$, barley grass ${ }^{35}$, and common edible fruits ${ }^{36}$. In this study, Pearson correlation coefficients $(R)$ indicated a relationship between the antioxidant activity, TPC, and TMAC of rice grass and wheatgrass juices (Table 3 ). The $R$ values indicated that the TPC and TMAC were involved in the DPPH radical scavenging activity, ferric reducing ability, and anti-lipid peroxidation activity of rice grass and wheatgrass juices. The TMAC in coloured rice grass juices was more associated with inhibitory effects on lipid peroxidation. The effective radical scavenging activity, ferric reducing ability, and anti-lipid peroxidation activity of rice grass and wheatgrass juices may result from a synergistic effect between phenolic compounds and other non-phenolic antioxidants. This synergistic effect in crude plant mixtures has also been re- ported by Vinson et al, who demonstrated that crude extracts from commonly consumed fruits exhibit higher antioxidant activity than most pure phenolic compounds and vitamin antioxidants ${ }^{31}$.

Reactive oxygen species (ROS) such as hydroperoxyl, superoxide, and hydroxyl radicals play an important role in oxidative DNA damage. This deleterious effect causes dysfunction in biological processes in the human body leading to age-related and chronic diseases ${ }^{37,38}$. Plant extracts that can scavenge ROS may prevent oxidative DNA damage $^{39}$. Our results indicated that rice grass and wheatgrass juices exhibit partial DNA protection against the Fenton reaction (Fig. 5). Only the Kum Doisaket cultivar, which contained the highest level of total monomeric anthocyanins, demonstrated a dose-dependent DNA protective effect. This result suggested that the anthocyanins in coloured rice grass juice may be responsible for these DNA protective effects. Anthocyanins can protect DNA from hydroxyl radicals generated in the Fenton reaction by forming an anthocyanin-DNA copigmentation complex $^{40}$. The dose-dependent DNA protective effect of rice grass juice from the Kum Doisaket cultivar is consistent with the DNA protective pattern of wheat sprout extract ${ }^{4}$. Rice grass juice from the Kum Noi cultivar also prevented hydroxyl radical-induced oxidative damage of pBR322 DNA. The DNA protective effect of the Kum Noi cultivar however was lower than that of the Kum Doisaket cultivar. The low level of total monomeric anthocyanins in the grass juice from the Kum Noi cultivar may affect its DNA protective properties.

This study is the first to report the antioxidant activity and the total phenolic and total monomeric anthocyanin content of juices squeezed from grasses harvested at the jointing stage from various Thai rice cultivars that included coloured and white rice. The findings of our study suggest that coloured rice grass juices that contain a high level of total monomeric anthocyanins exhibit higher antioxidant activity than white rice and wheat. Anthocyanins present in coloured rice grass juices are responsible for their high antioxidant efficacy. Notably, the coloured rice cultivar Kum Doisaket exhibited effective antioxidant activity and DNA protective properties and contains the highest level of anthocyanins. Thus coloured rice cultivars may be used as primary ingredients in food supplements or functional foods. These results are useful for the development of new functional foods from rice grass cocktails. Additional studies are necessary to isolate and characterize the bioactive compounds present 
in rice grass juice. Bioassay-guided fractionation and the elucidation of the mechanisms underlying the bioactivities of rice grass juice may aid in the development of value-added products from rice.

Acknowledgements: This study was financially supported by the Ratchadaphiseksomphot Endowment Fund of Chulalongkorn University (RES560530157-HR) and the 90th Anniversary of Chulalongkorn University Fund (Ratchadaphiseksomphot Endowment Fund). We also thank the Chulalongkorn University Centenary Academic Development Project for access to their facilities. We would like to acknowledge Dumnern Kaaladee; the Bureau of Seed Multiplication, Rice Department of Thailand; Kasem Kumsue; and Chuay Sasuk for providing rice seeds.

\section{REFERENCES}

1. Kulkarni SD, Tilak J, Acharya R, Rajurkar NS, Devasagayam TPA, Reddy AVR (2006) Evaluation of the antioxidant activity of wheatgrass (Triticum aestivum L.) as a function of growth under different conditions. Phytother Res 20, 218-27.

2. Gruenwald J (2009) Novel botanical ingredients for beverages. Clin Dermatol 27, 210-6.

3. Wigmore A (1985) The Wheatgrass Book, Avery Publishing Group, Wayne, New Jersey.

4. Falcioni G, Fedeli D, Tiano L, Calzuola I, Mancinelli L, Marsili V, Gianfranceschi G (2002) Antioxidant activity of wheat sprouts extract in vitro: Inhibition of DNA oxidative damage. $J$ Food Sci 67, 2918-22.

5. Hemalatha R, Karthik M, Narendra Babu K, Dinesh Kumar B (2012) Immunomodulatory activity of Triticum aestivum and its effects on Th1/Th2 cytokines and NFкB P 65 response. Am J Biochem Mol Biol 2, 19-29.

6. Calzuola I, Marsili V, Gianfranceschi GL (2004) Synthesis of antioxidants in wheat sprouts. J Agr Food Chem 52, 5201-6.

7. Lim TK (2013) Edible Medicinal and Non-Medicinal Plants: Vol. 5, Fruits, Springer, New York, pp 1, 301-49, 385-415.

8. Deng G-F, Xu X-R, Zhang Y, Li D, Gan R-Y, Li H-B (2013) Phenolic compounds and bioactivities of pigmented rice. Crit Rev Food Sci Nutr 53, 296-306.

9. Lin P-Y, Lai H-M (2011) Bioactive compounds in rice during grain development. Food Chem 127, 86-93.

10. Sutharut J, Sudarat J (2012) Total anthocyanin content and antioxidant activity of germinated coloured rice. Int Food Res $J$ 19, 215-21.

11. Laokuldilok T, Shoemaker CF, Jongkaewwattana S, Tulyathan V (2011) Antioxidants and antioxidant activity of several pigmented rice brans. J Agr Food Chem 59, 193-9.

12. Chen P-N, Kuo W-H, Chiang C-L, Chiou H-L, Hsieh Y-S, Chu S-C (2006) Black rice anthocyanins inhibit cancer cells invasion via repressions of MMPs and u-PA expression. Chem Biol Interact 163, 218-29.

13. Fasahat P, Abdullah A, Muhammad K, Karupaiah T, Ratnam W (2012) Red pericarp advanced breeding lines derived from Oryza rufipogon $\times$ Oryza sativa: physicochemical properties, total antioxidant activity, phenolic compounds and vitamin E content. $A d v$ J Food Sci Tech 4, 155-65.

14. Benjawan L, Jiwajinda S, Aroonrungsikul C, Vihokto S, Kunprom C (2010) Nutritional values of juice from Thai-rice leaves and product development. Research report, Kasetsart Univ (unpublished).

15. Brand-Williams W, Cuvelier ME, Berset C (1995) Use of a free radical method to evaluate antioxidant activity. LWT Food Sci Tech 28, 25-30.

16. Benzie IFF, Strain JJ (1996) The ferric reducing ability of plasma (FRAP) as a measure of "antioxidant power": the FRAP assay. Anal Biochem 239, 70-6.

17. Takada H, Kokubo K, Matsubayashi K, Oshima $\mathrm{T}$ (2006) Antioxidant activity of supramolecular watersoluble fullerenes evaluated by $\beta$-carotene bleaching assay. Biosci Biotechnol Biochem 70, 3088-93.

18. Tee PL, Yusof S, Mohamed S (2002) Antioxidative properties of roselle (Hibiscus sabdariffa L.) in linoleic acid model system. Nutr Food Sci 32, 17-20.

19. Nagababu E, Rifkind JM, Boindala S, Nakka L (2008) Assessment of antioxidant activity of eugenol in vitro and in vivo. In: Uppu RM, et al (eds) Methods in Molecular Biology Vol. 610, Humana Press, New York, pp 165-80.

20. Singleton VL, Orthofer R, Lamuela-Raventós RM (1999) Analysis of total phenols and other oxidation substrates and antioxidants by means of Folin-Ciocalteu reagent. In: Lester P (ed) Methods in Enzymology Vol. 299, Academic Press, New York, pp 152-78.

21. Lee J, Durst RW, Wrolstad RE (2005) Determination of total monomeric anthocyanin pigment content of fruit juices, beverages, natural colorants, and wines by the $\mathrm{pH}$ differential method: Collaborative study. $J$ AOAC Int 88, 1269-78.

22. Ben-Arye E, Goldin E, Wengrower D, Stamper A, Kohn R, Berry E (2002) Wheat grass juice in the treatment of active distal ulcerative colitis: A randomized double-blind placebo-controlled trial. Scand J Gastroenterol 37, 444-9.

23. Bar-Sela G, Tsalic M, Fried G, Goldberg H (2007) Wheat grass juice may improve hematological toxicity related to chemotherapy in breast cancer patients: A pilot study. Nutr Canc 58, 43-8.

24. Peryt B, Szymcyzyk T, Lesca P (1992) Mechanism of antimutagenicity of wheat sprout extracts. Mutat Res Fund Mol Mech Mutagen 269, 201-15.

25. Dudonné $S$, Vitrac $X$, Coutière $P$, Woillez $M$, Mérillon J-M (2009) Comparative study of antioxidant properties and total phenolic content of 30 plant extracts of industrial interest using DPPH, ABTS, FRAP, SOD, and ORAC assays. $J$ Agr Food Chem 57, 1768-74. 
26. Prior RL, Cao G (1999) In vivo total antioxidant capacity: Comparison of different analytical methods. Free Radic Biol Med 27, 1173-81.

27. Antolovich M, Prenzler PD, Patsalides E, McDonald S, Robards K (2002) Methods for testing antioxidant activity. Analyst 127, 183-98.

28. Frankel EN, Finley JW (2008) How to standardize the multiplicity of methods to evaluate natural antioxidants. J Agr Food Chem 56, 4901-8.

29. Moon J-K, Shibamoto T (2009) Antioxidant assays for plant and food components. J Agr Food Chem 57, 1655-66.

30. Rice-Evans CA, Miller NJ, Paganga G (1996) Structure-antioxidant activity relationships of flavonoids and phenolic acids. Free Radic Biol Med 20, 933-56.

31. Vinson JA, Su X, Zubik L, Bose P (2001) Phenol antioxidant quantity and quality in foods: Fruits. J Agr Food Chem 49, 5315-21.

32. Paśko P, Bartoń H, Zagrodzki P, Gorinstein S, Fołta M, Zachwieja Z (2009) Anthocyanins, total polyphenols and antioxidant activity in amaranth and quinoa seeds and sprouts during their growth. Food Chem 115, 994-8.

33. Dai J, Mumper RJ (2010) Plant phenolics: extraction, analysis and their antioxidant and anticancer properties. Molecules 15, 7313-52.

34. Banerjee A, Dasgupta N, De B (2005) In vitro study of antioxidant activity of Syzygium cumini fruit. Food Chem 90, 727-33.

35. Paulíčková I, Ehrenbergerová J, Fiedlerová V, Gabrovská D, Havlová P, Holasova M, Kopáček J, Ouhrabková J, et al (2006) Evaluation of barley grass as a potential source of some nutritional substances. Czech J Food Sci 25, 65-72.

36. García-Alonso M, de Pascual-Teresa S, Santos-Buelga C, Rivas-Gonzalo JC (2004) Evaluation of the antioxidant properties of fruits. Food Chem 84, 13-8.

37. Finkel T, Holbrook NJ (2000) Oxidants, oxidative stress and the biology of ageing. Nature 408, 239-47.

38. Mayne ST (2003) Antioxidant nutrients and chronic disease: use of biomarkers of exposure and oxidative stress status in epidemiologic research. J Nutr $\mathbf{1 3 3}$ 933S-40S.

39. Kapiszewska M, Sołtys E, Visioli F, Cierniak A, Zając G (2005) The protective ability of the Mediterranean plant extracts against the oxidative DNA damage. The role of the radical oxygen species and the polyphenol content. $J$ Physiol Pharmacol 56, Suppl 1, 183-97.

40. Sarma AD, Sharma R (1999) Anthocyanin-DNA copigmentation complex: Mutual protection against oxidative damage. Phytochemistry 52, 1313-8. 